$$
\text { JIME }
$$$$
\text { (Journal of Industrial and Manufacture Engineering) }
$$

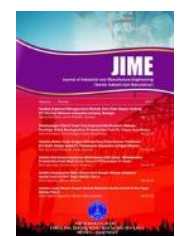

Available online http://ojs.uma.ac.id/index.php/jime

\section{Pengaruh Integrasi Pemasok pada Kinerja Rantai Pasok dengan Moderasi Gaya Kepemimpinan Transformasional Rantai Pasok pada Perusahaan Manufaktur di Batam}

\author{
Nasar Buntu Laulita \\ Universitas Internasional Batam
}

Diterima: April 2020; Disetujui: Mei 2021; Dipublikasi: Mei 2021;

*Coresponding author: nasar bl@yahoo.com.sg

\section{Abstrak}

Penelitian ini bertujuan untuk meneliti pengaruh integrasi pemasok terhadap kinerja rantai pasok dengan moderasi gaya kepemimpinan transformasional rantai pasok. Metodologi penelitian yang digunakan dalam penelitian ini adalah pengujian hipotesis dengan analisa menggunakan model persamaan struktural (SEM) dan analisa faktor konfirmatori (CFA) dengan menggunakan SPSS dan Lisrel. Populasi responden dari penelitian ini adalah 850 perusahaan manufaktur di Batam dengan pengumpulan data lewat kuesioner dan jumlah sampel yang memenuhi kriteria untuk dianalisa dari 171 perusahaan manufaktur yang diwakili oleh pimpinan di bagian manajemen rantai pasok. Hasil penelitian ini menunjukkan bahwa: (1) Integrasi Pemasok berpengaruh positif terhadap Kinerja Rantai Pasok dan signifikan; (2) Gaya Kepemimpinan Transformasional Rantai Pasok tidak signifikan momderasi hubungan integrasi pemasok dengan kinerja rantai pasok perusahaan; (3) Gaya Kepemimpinan Transformasional Rantai Pasok signifikan mempengaruhi kinerja rantai pasok perusahaan secara langsung. Hasil penelitian bisa menjadi rujukan bagi pengambil keputusan dan pimpinan manajemen rantai pasok untuk menerapkan strategi manajemen rantai pasok dalam bentuk integrasi dengan pemasok untuk meningkatkan kinerja rantai pasok perusahaan dan mempetimbangkan pengaruh gaya kepemimpinan transformasional rantai pasok untuk menjaga keberlangsungan hubungan jangka panjang dengan pemasok pada perusahaan multi nasional yang sudah mempunyai sistem yang baku dan standar.

Kata Kunci: integrasi pemasok, gaya kepemimpinan transformasional rantai pasok, kinerja rantai pasok, model persamaan struktural.

\begin{abstract}
This study aims to investigate the influence of supplier integration to supply chain performance by moderating effect of supply chain transformational leadership. The methodology of this research is an explanatory study by using structural equation modelling (SEM) and confirmatory factor analysis (CFA). The data's were collected from a convenience samples of 171 manufacturing companies of total 850 companies in Batam being represented by manager in supply chain management divisions. Data's were collected using questionnaire and technical data is analyzed by using SPSS dan Lisrel. The result of this study found that: (1) Supplier Integration affects Supply Chain Performance directly and significantly; (2) Supply chain transformational leadership doesn't moderate relationship between supplier integration and supply chain performance significantly; (3) Supply Chain Transformational Leadership affects Supply Chain Performance directly and significantly. The managerial implication of this research is as a guidance for decision maker in the company or manager in the supply chain management to implement supplier integration and supply chain transformational leadership a tools for maintaining the long term relationship for for multinational company that have fixed and standard system.

Keywords: supplier integration, supply chain transformational leadership style, supply chain performance, structural equation model
\end{abstract}

How to Cite: Laulita, Nasar Buntu (2021). Pengaruh Integrasi Pemasok Pada Kinerja Rantai Pasok dengan Moderasi Gaya Kepemimpinan Transformasional Rantai Pasok Pada Perusahaan Manufaktur di Batam. JIME (Journal of Industrial and Manufacture Engineering). 5(1): 20-29 


\section{PENDAHULUAN}

Beberapa penelitian menyebutkan bahwa strategi integrasi dengan pemasok akan berpengaruh dalam meningkatkan kinerja rantai pasok serta keunggulan bersaing seperti penelitian Stock et al. (2010), Danese (2013), Al-Tit (2017), He et al., 2016), sehingga hal ini sangat dibutuhkan dalam menghadapi persaingan ekonomi di tiap kawasan seperti AFTA (Asean Free Trade Area) karena kebijakan integrasi rantai pasok bisa menjaga pertumbuhan perusahaan secara berkesinambungan dan mendapatkan keuntungan. Hal ini menyebabkan perusahaan selalu berusaha beroperasi secara efisien dan fleksibel dalam rantai pasoknya untuk bisa bersaing seperti penelitian Moyano-Fuentes \& SacristánDíaz (2012) maupun Kumar et al. (2017) serta pengaruhnya dalam fleksibilitas suatu perusahaan manufaktur (Ivanov et al., 2018).

Beberapa peneliti seperti Flynn et al. (2010), Wong et al. (2011), Chang et al. (2015), Kumar et al. (2017), Vanpoucke et al. (2017) maupun Ivanov et al. (2018) menyatakan bahwa strategi manajemen rantai pasok dengan penerapan sistem yang terintegrasi antara pembeli dan pemasok pada perusahaan merupakan suatu pilihan strategi untuk bisa bersaing dan menghasilkan kinerja perusahaan yang optimal. Ketertarikan terhadap integrasi dalam rantai pasok mulai berkembang dan dianggap penting oleh perusahaan karena melihat adanya peluang dan keuntungan dari hubungan integrasi dalam rantai pasok sejak tahun 1980-an (Soosay et al., 2008). Penelitian tentang integrasi pemasok menunjukkan hubungan positif antara integrasi pemasok ataupun integrasi rantai pasok secara keseluruhan dan kinerja operasional maupun kinerja bisnis pembeli seperti penelitian dari Devaraj et al. (2007), Danese (2013), Vanpoucke et al. (2014), He et al. (2016), Vanpoucke et al. (2017) maupun Kumar et al. (2017) serta kaitannya dengan kinerja pemasok menurut Prahinski \& Benton (2004), Shin et al. (2000) maupun Bag (2018). Beberapa penelitian tidak membuktikan adanya hubungan langsung antara integrasi pemasok dan kinerja operasional rantai pasok, misalnya Stank et al. (2001) dan Flynn et al. (2010) atau integrasi pemasok dan kinerja bisnis (misalnya, Flynn et al. (2010) maupun pengaruhnya terhadap kinerja pemasok (Huang et al., 2014). Beberapa penelitian juga menemukan hubungan negatif antara integrasi pemasok dan kinerja operasional rantai pasok, misalnya Swink et al. (2007), Narasimhan et al. (2010), Sivadasan et al., (2010) maupun Abdallah et al. (2014).

Untuk memahami penyebab tidak samanya pengaruh integrasi pemasok dalam manajemen rantai pasok, maka menurut penelitian Akdogan \& Demirtas (2014), Defee et al. (2009); Defee et al. (2010); Gosling et al. (2016) serta Bag (2018) bahwa perlu untuk mengetahui hal-hal yang berkaitan dengan pimpinan rantai pasok dalam menjalankan strategi rantai pasok karena kepemimpinan sangat diperlukan dalam rantai pasok seperti penelitian Cooper et al. (1997), Gosling et al. (2016), Bag (2018) sebagai kunci sukses strategi dan keunggulan daya saing menurut Bass (1991) dan Waldman et al. (2001) serta keberhasilan dalam hubungan pembeli dan pemasok menurut penelitian Hsu et al. (2008), Liu et al. (2009) serta Bag (2018). 
Kepemimpinan selalu digambarkan sebagai tingkah laku dan sifat pribadi yang secara tidak sadar dibutuhkan dalam mempengaruhi proses suatu hubungan (Grint, 2005; Bolden et al., 2011; Gosling et al., 2016). Ini menyebabkan gaya kepemimpinan manajer merupakan faktor penting dalam kepeminpinan rantai pasok seperti penelitian Defee et al. (2009), Defee et al. (2010); Gosling et al. (2016) maupun Bag (2018) yang tidak hanya mempengaruhi perusahaan tetapi juga keseluruhan rantai pasok termasuk pemasok seperti penelitian Gosling et al. (2016) dan Bag (2018).

Gaya kepeminpinan rantai pasok pada umumnya dibedakan atas gaya kepemimpinan transaksional dan gaya kepemimpinan transformasional menurut penelitian Hult et al. (2000), Defee et al. (2009), Defee et al. (2010) serta Gosling et al. (2016). Kepemimpinan transaksional adalah kepemimpinan tradisional yang fokus pada perubahan yang terjadi antara pemimpin dan pengikut, dimana perubahan ini memungkinkan para pemimpin untuk mencapai target kinerjanya, melengkapi tugas yang diperlukan, menjaga kondisi organisasi, memotivasi pengikut melalui perjanjian kontrak, memastikan perilaku langsung dari pengikut menuju pencapaian target yang ditetapkan, menekankan penghargaan dari luar, menghindari resiko yang tidak perlu, dan fokus pada peningkatan efisiensi organisasi (Bass, 1985; Bass, 1991; Bass, 2000; Bass, 2008; Burns, 1978; Hult et al., 2000), sedang kepemimpinan transformasional lebih sering menunjukkan empat komponen yaitu mempengaruhi lewat ide, memberikan inspirasi dan memotivasi, memberikan stimulasi intelektual, dan memberikan pertimbangan individual (Hult et al., 2000; McCleskey, 2014). Gaya kepemimpinan transformasional rantai pasok juga akan berperan dalam meningkatkan kualitas integrasi dengan pemasok dan menjaga hubungan jangka panjang dengan pemasok (Hult et al., 2000) serta penerapan strategi manajemen rantai pasok secara luas (Gosling et al, 2016) karena gaya kepemimpinan transformasional mengarahkan pengikut dengan motivasi lewat perubahan pola pikir sehingga kinerja yang diharapkan bisa berlangsung dalam jangka panjang (Bass, 1985; Jung \& Avolio, 2000; Iqbal et al., 2015). Berdasarkan kesenjangan dari penelitian sebelumnya mengenai pengaruh integrasi pemasok dalam manajemen rantai pasok, maka penelitian ini menggunakan gaya kepemimpinan rantai pasok transformasional sebagai variabel moderasi yang bisa mempengaruhi penerapan integrasi rantai pasok terkhusus integrasi dengan pemasok terhadap kinerja rantai pasok serta memperkuat penelitan-penelitian sebelumnya bahwa gaya kepemimpinan berhubungan positif dengan kinerja perusahaan seperti penelitian Harland et al. (2007), Defee et al. (2009; Defee et al. (2010), Morali \& Searcy (2013), Gosling et al. (2016) maupun Bag (2018).

Berdasarkan hal-hal diatas, rerangka penelitian seperti ditunjukkan di gambar dibawah. 


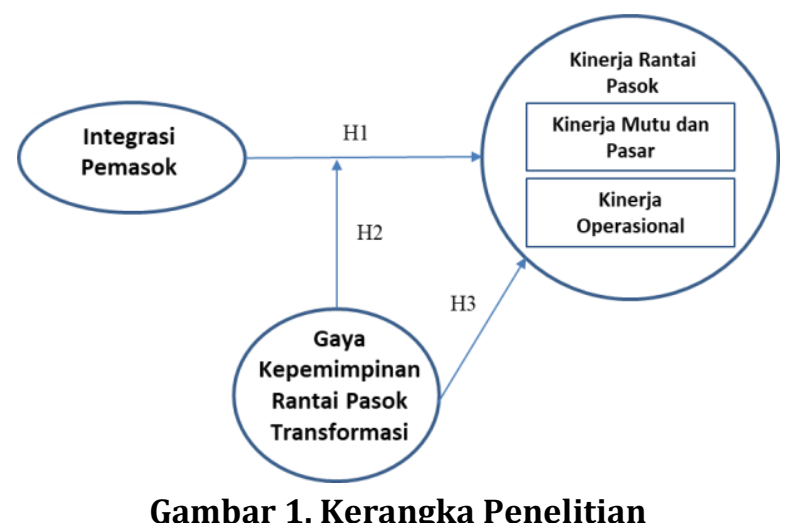

H1: Integrasi pemasok mempengaruhi kinerja rantai pasok perusahaan

H2: Gaya kepemimpinan transformasional rantai pasok memoderasi hubungan integrasi pemasok dan kinerja rantai pasok perusahaan

H3: Gaya kepemimpinan transformasional rantai pasok berpengaruh langsung terhadap kinerja rantai pasok

Menurut Jajja et al. (2016), kinerja rantai pasok adalah variabel hasil dari hubungan pembeli dan pemasok. Miguel dan Brito (2011) juga menjelaskan bahwa literatur manajemen rantai pasok lahir dari dampak positif penerapannya terhadap kinerja perusahaan, dimana kinerja menunjukkan efisiensi dan efektivitas manajemen rantai pasok secara keseluruhan. Di samping itu, langkahlangkah operasional dimasukkan karena berkaitan langsung dengan hubungan antara mitra rantai pasok dan termasuk langkah-langkah waktu pengembangan produk baru (McIvor dan Humphreys, 2004; Jajja et al., 2016), waktu tunggu (Humphreys et al., 2004; Jajja et al., 2016), kinerja pengiriman (Tan et al., 2002; Jajja et al., 2016), respon dan keandalan produk (Shin et al., 2000; Jajja et al., 2016), kepuasan pelanggan (Flamholtz dan Kannan-Narasimhan, 2005; Jajja et al., 2016) dan waktu siklus manufaktur (Naylor et al., 1999; Jajja et al., 2016).
Gawankar et al. (2017) juga secara terperinci membagi pengukuran kinerja manajemen rantai pasok berdasarkan pengukuran tradisional (fleksibilitas rantai pasok, integrasi rantai pasok, respon ke pelanggan, efisiensi, mutu, inovasi produk, kinerja pasar) dan pengukuran hubungan (mutu hubungan, kinerja pemasok) ataupun secara umum dalam bentuk kinerja mutu dan pasar serta kinerja operasional menurut Jajja et al. (2016).

Integrasi pemasok merupakan bagian dari integrasi rantai pasok yang bisa didefinisikan sebagai hubungan erat, jangka panjang, dan kerjasama yang dibangun antara perusahaan dan mitra rantai pasoknya (Prajogo dan Olhager, 2012), dengan pemasok terlibat dalam proses pengambilan keputusan penting perusahaan serta berbagi informasi mengenai perkiraan permintaan, produksi dan tingkat persediaan (Kumar et al., 2017). Integrasi pemasok dapat digunakan sebagai sinonim untuk istilah lain, seperti hubungan pembeli dan pemasok, keterlibatan pemasok, dan kolaborasi pemasok (Squire et al., 2009). Integrasi pemasok yang efektif merupakan strategi penting bagi perusahaan yang ingin mencapai keunggulan bersaing (Stock et al., 2010; Danese, 2013; Kumar et al., 2017; Vanpoucke et al., 2017; He et al., 2016) dan strategi terbaik dalam mencapai kinerja rantai pasok yang andal (Lee et al., 2007).

\section{METODE PENELITIAN}

Penelitian ini menggunakan pengujian hipotesis yang meneliti hubungan antara dua atau lebih variabel yang dinyatakan dalam bentuk pernyataan yang mewakili tiap variabel sehingga dapat diperoleh kesimpulan dari penelitian yang dilakukan (Sekaran \& 
Nasar Buntu Laulita. Pengaruh Integrasi Pemasok Pada Kinerja Rantai Pasok dengan Moderasi Gaya Kepemimpinan Transformasional Rantai Pasok Pada Perusahaan Manufaktur di Batam.

Bougie, 2016). Metodologi penelitian ditunjukkan di gambar 2. Berdasarkan strategi yang dilakukan dalam penelitian, maka penelitian ini termasuk penelitian survei yang mengumpulkan informasi dari atau tentang orang-orang untuk menggambarkan, membandingkan, atau menjelaskan tentang pengetahuan, sikap dan prilaku mereka (Sekaran \& Bougie, 2016). Penelitian ini menggunakan unit analisis tentang perusahaan yang diwakili oleh salah satu dari manajer pada bagian manajemen rantai (Sekaran \& Bougie, 2016). Berdasarkan pada horizon waktu, penelitian ini termasuk penelitian cross sectional dimana data hanya sekali dikumpulkan dalam periode tertentu (Sekaran \& Bougie, 2016). Periode penelitian ini adalah dari July - August 2019.

Populasi dalam penelitian ini adalah perusahaan manufaktur di Batam. Dua ratus lima puluh kuesioner disebarkan pada setiap perusahaan dan 171 responden yang layak diuji. Menurut Hair et al. (2018), MLE (maximum likelihood estimation) memberikan hasil yang valid dan stabil dengan jumlah sampel paling kecil 50 atau ukuran sampel antara 100 sampai 400 disarankan dengan berbagai pertimbangan. Hair et al. (2018) lebih lanjut menjelaskan bahwa minimum sampel 150 dibutuhkan untuk model dengan maksimal tujuh variabel, modest communalities (0.5) dan tidak ada variabel yang tidak teridentifikasi.

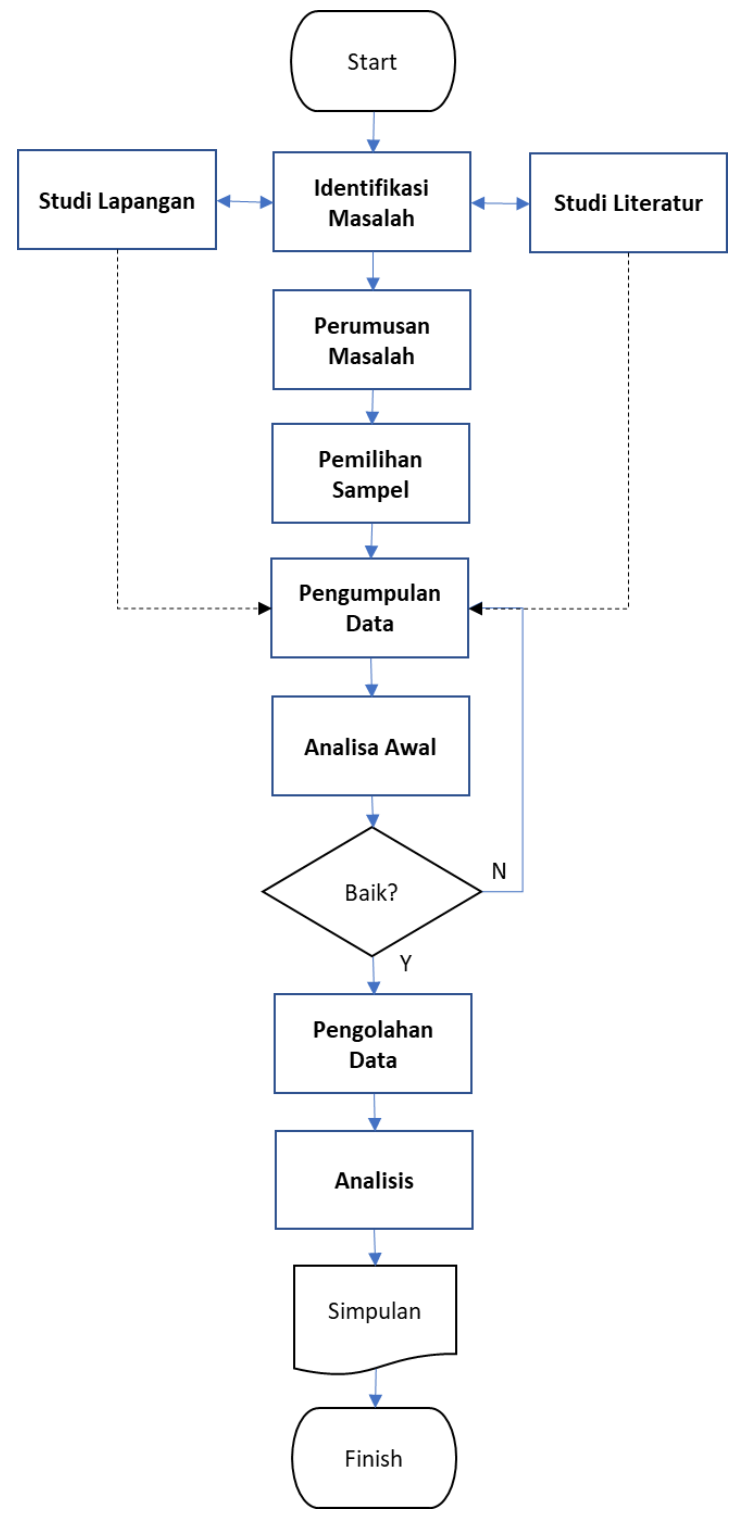

Gambar 2. Metodologi Penelitian

Integrasi pemasok diukur dengan dengan menggunakan 7 (tujuh) item pernyataan yang diadaptasi dari Cao et al. (2015), gaya kepemimpinan transformasional rantai pasok diukur dengan 5 (lima) item pernyataan yang diadopsi dari Hult et al. (2000) dan kinerja rantai pasok diukur dengan dengan menggunakan 10 (sepuluh) item pernyataan yang diadaptasi dari Jajja et al. (2016). Model persamaan struktur penelitian ditunjukkan di gambar 3. 


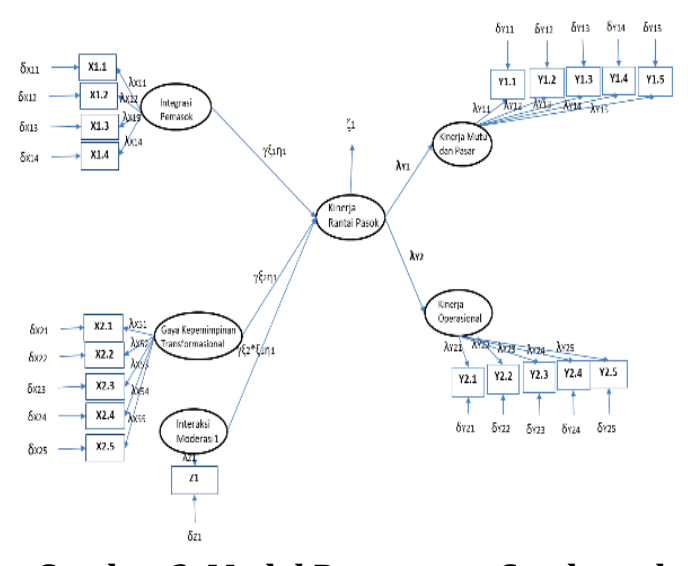

Gambar 3. Model Persamaan Struktural

\section{HASIL DAN PEMBAHASAN}

Tabel 1. Profil Perusahaan

\begin{tabular}{lcc}
\hline & Frek & \% \\
\hline Lama Berdiri & & \\
0 - 5 tahun & 4 & 2.3 \\
- - 10 tahun & 24 & 14 \\
$>$ 10 tahun & 143 & 83.3 \\
Jenis Industri & & \\
Electronik & 85 & 49.7 \\
Plastik & 48 & 28.1 \\
Logam & 27 & 15.8 \\
Lainnya & 11 & 6.4 \\
lumlah Karyawan & & \\
100 - 250 & 53 & 31 \\
251 - 500 & 98 & 57.3 \\
$>$ 500 & 20 & 11.7 \\
Penjuakan/Tahun & & \\
USD 200K- 4 M & 78 & 45.6 \\
$>$ USD 4 M & 93 & 54.4 \\
\% Pemasok Kunci di & & \\
< 50\% & 45 & 26.3 \\
Lanjutan tabel 1 & & \\
\hline & Frek & \% \\
\hline 50\% - 75\% & 78 & 45.6 \\
$>$ 75\% & 48 & 28.1 \\
\hline Sumber: SPSS 22.0 & &
\end{tabular}

Tabel 2. Profil Manajer Rantai Pasok

\begin{tabular}{lcc}
\hline & Frekuensi & \% \\
\hline Gender & & \\
Male & 96 & 56.1 \\
Female & 75 & 43.9 \\
Education & & \\
< Degree & 34 & 19.9 \\
Degree & 132 & 77.2
\end{tabular}

\begin{tabular}{lcc}
\hline & Frekuensi & $\mathbf{\%}$ \\
\hline Master & 5 & 2.9 \\
Working & & \\
< 5 years & 12 & 7 \\
5 - 10 years & 111 & 64.9 \\
$>10$ years & 48 & 28.1 \\
Total Working & & \\
$<5$ years & 0 & 0 \\
5 - 10 years & 17 & 9.9 \\
$>10$ years & 154 & 90.1 \\
\hline Sumber: Hasil Pengolahan dengan SPSS 24.0
\end{tabular}

Persepsi responden terhadap integrasi pemasok, kinerja pemasok, dan kinerja rantai pasok ditunjukkan di tabel 3, 4 dan 5.

Tabel 3. Integrasi Pemasok

\begin{tabular}{ccc}
\hline Indikator & SD & Mean \\
\hline SI1 & 0.642 & 4.275 \\
SI2 & 0.716 & 4.199 \\
SI3 & 0.619 & 4.263 \\
SI4 & 0.792 & 4.053 \\
SI5 & 0.752 & 4.152 \\
SI6 & 0.628 & 4.316 \\
SI7 & 0.646 & 4.316 \\
Integrasi & 0.685 & 4.225 \\
Pemasok & \\
\hline \multicolumn{3}{l}{ rasil Pengolahan dengan SPSS 24.0 }
\end{tabular}

Tabel 4. Gaya Kepemimpinan Rantai Pasok Transformasional

\begin{tabular}{ccc}
\hline Indikator & SD & Mean \\
\hline GK1 & 0.787 & 3.801 \\
GK2 & 0.819 & 3.813 \\
GK3 & 0.824 & 3.819 \\
GK4 & 0.833 & 3.795 \\
GK5 & 0.779 & 3.801 \\
\hline
\end{tabular}

Sumber: SPSS 24.0

Tabel 5. Kinerja Rantai Pasok

\begin{tabular}{cccc}
\hline Dimensi & Indikator & SD & Mean \\
\hline \multirow{4}{*}{ MP } & MP1 & 0.626 & 4.234 \\
& MP2 & 0.675 & 4.181 \\
& MP3 & 0.642 & 4.228 \\
& MP4 & 0.662 & 4.310 \\
KO & MP5 & 0.648 & 4.322 \\
& KO1 & 0.633 & 4.304 \\
& KO2 & 0.720 & 4.228 \\
& KO3 & 0.621 & 4.222
\end{tabular}


Nasar Buntu Laulita. Pengaruh Integrasi Pemasok Pada Kinerja Rantai Pasok dengan Moderasi Gaya Kepemimpinan Transformasional Rantai Pasok Pada Perusahaan Manufaktur di Batam.

\begin{tabular}{cccc}
\hline Dimensi & Indikator & SD & Mean \\
\hline & K04 & 0.658 & 4.328 \\
K05 & 0.635 & 4.234 \\
Kinerja Rantai Pasok & 0.652 & 4.227
\end{tabular}

Sumber: LISREL 8.7

Confirmatory Factor Analysis (CFA) untuk mengetahui Validitas dan Reliabilitas indikator tiap konstruk penelitian serta kelayakan model (Goodness of Fit) ditunjukkan di tabel 6,7,8, 9 dan 10.

Tabel 6. Uji Validitas dan Reliabilitas Integrasi Pemasok

\begin{tabular}{cccccc}
\hline Ind & $\lambda$ & AVE & VT & CR & RT \\
\hline SI1 & 0.75 & & Valid & & \\
SI2 & 0.66 & & Valid & & \\
SI3 & 0.82 & & Valid & & \\
SI4 & 0.68 & 0.55 & Valid & 0.85 & Baik \\
SI5 & 0.71 & & Valid & & \\
SI6 & 0.78 & & Valid & & \\
SI7 & 0.77 & & Valid & & \\
\hline
\end{tabular}

Sumber: LISREL 8.7

Tabel 7. Uji Validitas dan Reliabilitas Gaya Kepemimpinan Rantai Pasok Transformasional

\begin{tabular}{cccccc}
\hline Ind & $\lambda$ & AVE & VT & CR & RT \\
\hline GK1 & 0.94 & & Valid & & \\
GK2 & 0.52 & & Valid & & \\
GK3 & 0.56 & 0.54 & Valid & 0.87 & Baik \\
GK4 & 0.83 & & Valid & & \\
GK5 & 0.73 & & Valid & & \\
\hline
\end{tabular}

Sumber: Hasil Pengolahan dengan LISREL 8.7

Tabel 8. Uji Validitas dan Reliabilitas Kinerja Pemasok First Construct

\begin{tabular}{cccccc}
\hline Dms & $\lambda$ & AVE & CR & VT & RL \\
\hline MP & 0,60 & & & Valid & \\
HP & 0,82 & \multirow{2}{*}{0,55} & 0,83 & Valid & Baik \\
FP & 0,64 & & & Valid & \\
PP & 0,87 & & & Valid & \\
\hline
\end{tabular}

Sumber: Hasil Pengolahan dengan LISREL 8.7

Tabel 9. Uji Validitas dan Reliabilitas Kinerja Rantai Pasok First Construct

\begin{tabular}{lccccc}
\hline \multicolumn{1}{c}{ Dms } & $\lambda$ & AVE & CR & VT & RT \\
\hline KMP & 0,94 & 0,86 & 0,91 & Valid & Baik \\
KO & 0.91 & & & Valid & \\
\hline
\end{tabular}

Sumber: Hasil Pengolahan dengan LISREL 8.7
Tabel 10. Uji Kelayakan Model (GOF)

\begin{tabular}{|c|c|c|c|}
\hline Item & Target & $\begin{array}{c}\text { Hasil } \\
\text { Estimasi }\end{array}$ & Kes \\
\hline \multicolumn{4}{|c|}{ Ukuran Absolute Fit } \\
\hline RMSEA & $0.05-0.08$ & 0,069 & $\begin{array}{c}\text { Good } \\
\text { Fit }\end{array}$ \\
\hline $\begin{array}{c}\text { CI untuk } \\
\text { RMSEA }\end{array}$ & $0.00-0.10$ & $\begin{array}{l}0.00- \\
0.098\end{array}$ & $\begin{array}{c}\text { Good } \\
\text { Fit }\end{array}$ \\
\hline GFI & $\begin{array}{l}>0.80,>0.9 \\
0 \\
\text { Ukuran Incr }\end{array}$ & $\begin{array}{c}1.00 \\
\text { emental Fit }\end{array}$ & $\begin{array}{c}\text { Good } \\
\text { Fit }\end{array}$ \\
\hline NNFI & $>0,90$ & 1.02 & $\begin{array}{c}\text { Good } \\
\text { Fit }\end{array}$ \\
\hline CFI & $>0,90$ & 1.00 & $\begin{array}{c}\text { Good } \\
\text { Fit }\end{array}$ \\
\hline IFI & $>0,90$ & 1.00 & $\begin{array}{c}\text { Good } \\
\text { Fit }\end{array}$ \\
\hline NFI & $\begin{array}{l}>0.80,>0.9 \\
0 \\
\text { Ukuran } \mathrm{Pa}\end{array}$ & $\begin{array}{c}1.00 \\
\text { simony Fit }\end{array}$ & $\begin{array}{c}\text { Good } \\
\text { Fit }\end{array}$ \\
\hline $\begin{array}{l}\text { AIC dan } \\
\text { CAIC }\end{array}$ & $\begin{array}{l}\text { Nilai model } \\
<\quad \text { model } \\
\text { saturated }\end{array}$ & $\begin{array}{c}\text { AIC: } 26.48 \\
<30.00 \\
\text { CAIC: } \\
80.32< \\
92.12\end{array}$ & $\begin{array}{c}\text { Good } \\
\text { Fit }\end{array}$ \\
\hline AGFI & & 0.99 & Good \\
\hline ECVI & $\begin{array}{l}\text { Nilai } \\
\text { default } \\
\text { model < } \\
\text { model } \\
\text { saturated }\end{array}$ & $0.18<2.87$ & $\begin{array}{c}\text { Good } \\
\text { Fit }\end{array}$ \\
\hline
\end{tabular}

Hasil tabel menunjukkan bahwa indikator tiap konstruk memiliki nilai loading factor $\geq 0.50$, nilai $\mathrm{AVE} \geq 0.50$ dan nilai $\mathrm{CR} \geq 0.60$. Sehingga dapat disimpulkan bahwa semua indikator tersebut valid dan reliabel serta dapat mengukur konstruk dengan tepat (Hair et al., 2018). Hair et al. (2018) juga menyatakan bahwa dari beberapa hasil pengujian absolute fit measure dan incremental fit measure yang ada, apabila hasil satu pengujian fit, maka dapat disimpulkan bahwa model yang digunakan fit. Berdasarkan hasil tabel diatas, maka dari hasil pengujian goodness of fit dapat dinyatakan model penelitian dinyatakan good fit karena dilihat dari nilai RMSEA, GFI, NNFI, CFI, IFI, NFI, PGFI, ECFI, AIC dan 
CAIC sehingga model dinyatakan lolos uji goodness of fit dan dapat dilakukan tahap pengujian berikutnya.

Dari hasil uji hipotesa dengan Lisrel 8.7, diperoleh hasil seperti tabel 11 dibawah:

Tabel 11.Hasil Pengujian Hipotesa

\begin{tabular}{|c|c|c|c|}
\hline Hip & $\begin{array}{l}\text { Koefisien } \\
\text { Pengaruh } \\
(\gamma \text { atau } \beta)\end{array}$ & $\begin{array}{c}t- \\
\text { value }\end{array}$ & Keputusan \\
\hline H1 & 0.39 & 5.28 & $\begin{array}{c}\mathrm{H} 1 \\
\text { didukung }\end{array}$ \\
\hline $\mathrm{H} 2$ & -0.01 & -0.14 & $\begin{array}{l}\text { H2 tidak } \\
\text { didukung }\end{array}$ \\
\hline H3 & 0.29 & 4.02 & $\begin{array}{c}\mathrm{H} 3 \\
\text { didukung }\end{array}$ \\
\hline
\end{tabular}

Sumber: Output SEM dengan Lisrel 8.7

\section{KESIMPULAN}

Berdasarkan uji hipotesa yang dilakukan, dapat disimpulkan bahwa strategi manajemen rantai pasok dalam bentuk integrasi pemasok diperlukan dalam meningkatkan kinerja rantai pasok perusahaan manufaktur di Batam dan tidak signifkannya gaya kepemimpinan transformasional rantai pasok dalam memoderai hubungan integrasi pemasok dan kinerja rantai pasok karena sampel perusahaan dalam penelitian ini mayoritas perusahaan multinasional yang sudah memiliki sistem yang baku serta integrasi pemasok sudah merupakan kebijakan dari perusahaan tetapi gaya kepemimpinan rantai pasok tetap berpengaruh dalam menjaga hubungan jangka panjang dengan pemasok dan berdampak langsung pada peningkatan kinerja rantai pasok seperti penelitian Hult et al. (2000).

\section{DAFTAR PUSTAKA}

Abdallah, A. B., Obeidat, B. Y., \& Aqqad, N. O. (2014). The Impact of Supply Chain Management
Practices on Supply Chain Performance in Jordan: The Moderating Effect of Competitive Intensity. International Business Research, 7(3), 13-27.

Akdogan, A. A., \& Demirtas, 0. (2014). Managerial role in strategic supply chain management. Procedia-Social and Behavioral Sciences, 150, 1020-1029.

Al-Tit, A. A. (2017). Factors affecting the organizational performance of manufacturing firms. International Journal of Engineering Business Management, 9, 1-9.

Bag, S. (2018). Supplier Management and Sustainable Innovation in Supply Networks: An Empirical Study. Global Business Review, 19(3), 176-195.

Bass, B. M. (1985). Leadership and performance beyond expectations. Free Press.

Bass, B. M. (1991). From transactional to transformational leadership: Learning to share the vision. Organizational Dynamics, 18(3), 19-31.

Bass, B. M. (2000). The future of leadership in learning organizations. Journal of Leadership \& Organizational Studies, 7(3), 18-40.

Bass, B. M. (2008). The Bass handbook of leadership: Theory, research, \& managerial applications (4th ed.). Free Press.

Bolden, R., Hawkins, B., Gosling, J., \& Taylor, S. (2011). Exploring Leadership: Individual, Organizational and Societal Perpectives. Oxford University Press.

Burns, J. M. (1978). Leadership. Harper and Row.

Cao, Z., Huo, B., Li, Y., \& Zhao, X. (2015). The impact of organizational culture on supply chain integration: A contingency and configuration approach. Supply Chain Management: An International Journal, 20(1), 24-41.

Chang, W., Ellinger, A. E., Kim, K. (K. ), \& Franke, G. R. (2015). Supply chain integration and firm financial performance: A meta-analysis of positional advantage mediation and moderating factors. European Management Journal, 1-14.

Cooper, M. C., Lambert, D. M., \& Pagh, J. D. (1997). Supply chain management: More than a new name for logistics. International Journal Logistics Management, 8(1), 1-14.

Danese, P. (2013a). Supplier integration and company performance: A configurational view. Omega, 41(6), 1029-1041. 
Nasar Buntu Laulita. Pengaruh Integrasi Pemasok Pada Kinerja Rantai Pasok dengan Moderasi Gaya Kepemimpinan Transformasional Rantai Pasok Pada Perusahaan Manufaktur di Batam.

Danese, P. (2013b). Supplier integration and company performance: A configurational view. Omega, 41(6), 1029-1041.

Defee, C. C., Stank, T. P., \& Esper, T. L. (2010). Performance implications of transformational supply chain leadership and followershipw. Journal Physics Distribution Logistics Management, 4(10), 763-791.

Defee, C. C., Stank, T. P., Esper, T. L., \& Mentzer, J. T. (2009). Leveraging closed-loop orientation and leadership for environmental sustainability. Supply Chain Management an International Journal, 14(2), 87-98.

Devaraj, S., Krajewski, L., \& Wei, J. C. (2007). Impact of e-business technologies on operational performance: The role of production information in the supply chain. Journal of Operations Management, 25(6), 1199-1216.

Flynn, B. B., Huo, B., \& Zhao, X. (2010). The impact of supply chain integration on performance: A contingency and configuration approach. Journal of Operation Management, 28, 58-71.

Gosling, J., Jia, F., Gong, Y., \& Brown, S. (2016). The role of supply chain leadership in the learning of sustainable practice: Toward an integrated framework. Journal of Cleaner Production, 30, 1-12.

Grint, K. (2005). Problems, problems, problems: The social construction of leadership. Humanity Relationship, 58(11), 1467-1494.

Hair, J. F., Babin, B. J., Anderson, R. E., \& Black, W. C. (2018). Multivariate Data Analysis (8th ed.). Pearson Prentice Hall.

Harland, C. M., Caldwell, N. D., Powell, P., \& Zheng, J. (2007). Barriers to supply chain information integration: SME's a drift of e-Lands. Journal Operation Management, 25(6), 1234-1254.

He, Y., Sun, H., Ni, W., \& Ng, S. C. H. (2016). Reexamining the effects of supplier integration on operations performance: A relational view. International Journal of Operations \& Production

Management, https://doi.org/10.1108/ IJOPM-04-20160205.

Hsu, C. C., Kannan, V. R., Tan, K. C., \& Keong, L. G. (2008). Information sharing, buyer-supplier relationships, and firm performance: A multi-region analysis. International Journal of Physical Distribution \& Logistics Management, 38(4), 296-310.
Huang, M.-C., Yen, G.-F., \& Liu, T.-C. (2014). Reexamining supply chain integration and the supplier's performance relationships under uncertainty. Supply Chain Management: An International Journal, 19(1), 64-78.

Hult, G. T. M., Ferrel, O. C., Hurley, R. F., \& Giunipero, L. C. (2000). Leadership and relationship commitment a focus on the supplier-buyeruser linkage. Industrial Marketing Management, 29(2), 111-119.

Iqbal, N., Anwar, S., \& Haider, N. (2015). Effect of Leadership Style on Employee Performance. Arabian Journal of Business and Management Review, 5(5), 1-6.

Ivanov, D., Das, A., \& Choi, T. -M. (2018). New flexibility drivers for manufacturing, supply chain and service operations. International Journal of Production Research, 1-10.

Jajja, M. S. S., Kannan, V. R., Brah, S. A., \& Hassan, S. Z. (2016). Supply chain strategy and the role of suppliers: Evidence from the Indian subcontinent. Benchmarking: An International Journal, 23(7), 1658-1676.

Jung, D., \& Avolio, B. (2000). Opening the black box: An experimental investigation of the mediating effects of trust and value congruence on transformational and transactional leadership. Journal of Organizational Behavior, 21, 949-964.

Kumar, V., Chibuzo, E. N., Garza-Reyes, J. A., Kumari, A., Rocha-Lona, L., \& Lopez-Torres, G. C. (2017). The impact of supply chain integration on performance: Evidence from the UK Food Sector. Procedia Manufacturing, $11,814-821$.

Liu, Y., Luo, Y., \& Liu, T. (2009). Governing buyersupplier relationships through transactional and relational mechanisms: Evidence from China. Journal of Operations Management, 27(4), 294-309.

McCleskey, J. A. (2014). Situational, Transformational, and Transactional Leadership and Leadership Development. Journal of Business Studies Quarterly, 5(4), 117-130.

Morali, O., \& Searcy, C. (2013). A review of sustainability supply chain management practices in Canada. Journal Business Ethics, 117(3), 635-658.

Moyano-Fuentes, J., \& Sacristán-Díaz, M. (2012). Learning on lean: A review of thinking and 
research. International Journal Operations Production Management, 32(5), 551-582.

Narasimhan, R., Swink, M., \& Viswanathan, S. (2010). On decisions for integration implementation: An examination of complementarities between product-process technology integration and supply chain integration. Decision Sciences, 41(2), 355372.

Prahinski, C., \& Benton, W. C. (2004). Supplier evaluations: Communication strategies to improve supplier performance. Journal of Operations Management, 22(1), 39-62.

Sekaran, U., \& Bougie, R. (2016). Research methods for business: A skill-building approach (7th ed.).

Shin, H., Collier, D. A., \& Wilson, D. D. (2000). Supply management orientation and supplier/ buyer performance. Journal of Operations Management, 18(3), 317-333.

Sivadasan, S., Smart, J., Huatuco, L. H., \& Calinescu, A. (2010). Operational Complexity and Supplier-Customer Integration: Case studies insights and complexity rebound. Journal of the Operational Research Society (JORS), 61(12), 1709-1718.

Soosay, C. A., Hyland, P. W., \& Ferrer, M. (2008). Supply chain collaboration: Capabilities for continuous innovation. Supply Chain Management, 13(2), 160-169.

Stank, T. P., Keller, S. B., \& Daugherty, P. J. (2001). Supply chain collaboration and logistical service performance. Journal of Business Logistics, 22(1), 29-48.

Stock, J. R., Boyer, S. L., \& Harmon, T. (2010). Research opportunities in supply chain management. Journal of the Academy of Marketing Science, 38(1), 32-41.

Swink, M., Narasimhan, R., \& Wang, C. (2007). Managing beyond the factory walls: Effects of four types of strategic integration on manufacturing plant performance. Journal of Operation Management, 25(1), 148-164.

Vanpoucke, E., Vereecke, A., \& Boyer, K. K. (2014). Triggers andpatterns of integration initiatives in successful buyer-supplier relationships. Journal of Operations Management, 32(1), 15-33.

Vanpoucke, E., Vereecke, A., \& Muylle, S. (2017). Leveraging the impact of supply chain integration through information technology. International Journal of Operations \& Production Management, 37(4), 510-530.

Waldman, D. A., Ramirez, G. G., House, R. J., \& Puranan, P. (2001). Does leadership matter? CEO leadership attributes and profitability under conditions of perceived environmental uncertainty. Academic Management Journal, 44(1), 134-143.

Wong, C. Y., Boonitt, S., \& Wong, C. W. Y. (2011). The contingency effects of environmental uncertainty on the relationship between supply chain integration and operational performance. Journal of Operations Management, 9(6), 604-615. 